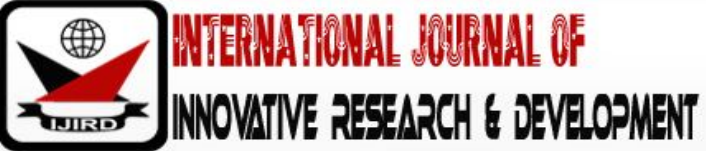

ISSN 2278 - 0211 (Online)

\section{Jatropha Oil Extraction Optimization through Varied Processing Conditions Using Mechanical Process}

\author{
Ajav, Emmanuel Atto \\ Professor, Department of Agricultural \& Environmental Engineering, \\ University of Ibadan, Ibadan, Nigeria \\ Okusanya, Muyiwa Abiodun \\ Lecturer, Department of Agricultural \&Bio- Environmental Engineering Technology, \\ Federal Polytechnic Ilaro, Nigeria \\ Obi, Okey Francis \\ Lecturer, Department of Agricultural \& Bio-Resources Engineering, \\ University of Nigeria, Nsukka, Nigeria
}

\begin{abstract}
:
This endeavour contains technical report on a project carried out on development of an expeller for Jatropha oil extraction. Parameters varied while evaluating the machine were hull fraction, heating time, number of pass and discharge gate opening. The parameters were varied to determine the condition under which maximum oil recovery, efficiency, and throughput capacity will be achieved. The effect of the varied parameters on the quality of the oil was determined by carrying out analysis on few samples to determine its physicochemical properties at some of the varied conditions. Depending on the defined limitations, the strainer press throughput was evaluated as $17 \mathrm{~kg} / \mathrm{hr}$. Maximum efficiency of $61 \%$ was recorded at 80 $\%$ hull fraction with single pass and best heating time of 20 minutes. With double pass, the efficiency rose to an average value of $80 \%$. In confirming its suitability for other oil crops, variables like shell fraction of $40 \%$ gave efficiency of the machine for groundnut oil seeds as $72.03 \%$, single pass. For castor, the efficiency was estimated as $62.5 \%$, single pass. Taking into consideration all the test results, optimal oil recovery is expected at $7 \%$ moisture content, cooking time of about 20 minutes, hull fraction of $80 \%$ and above, discharge gate opening of $4 \mathrm{~mm}$ and low speed of $30 \mathrm{rev} / \mathrm{min}$ or less. Additional research should be carried out using other relevant processes to provide better insight on how to achieve process efficiencies and viabilities that have close resemblance with industrial practice.
\end{abstract}

Keywords: Choke adjuster, oil recovery, throughput capacity, physicochemical characteristics of the oil, versatility of operation

\section{Introduction}

Oil crisis of 1973 and Energy crisis of 1979 have provided initial impetus for the world to seek alternatives to energy from fossil sources. Countries like Brazil and other developed nations have become increasingly dependent on green oil at a time of rising and volatile fuel prices like this, in the industry, transport system and even domestically. Other developing nations, like Nigeria should not be a let out in the search for alternative energy sources, more so that there is sudden alarming hike in petroleum prices by the current administration due to sharp drop in the price of crude oil per barrel in the world market - the shock is a big hit for the nation as she is always known for her monoculture economy.

In view of the depleting oil reserves and exponential rise in population demand for petroleum products, the search for alternative sources of fuel is very timely and important. The search for a cleaner and more secure energy source is a boon to any economy, particularly the developing ones. One of the most reliable alternative fuels which can be quickly integrated into existing transport structure is biodiesel from non-edible oil seeds like Jatropha Curcas Lini (JCL).

According to Anjan et al (2009), since the 1970s, the world's attention has been focused on depleting oil reserves, rising demand for petroleum products and consequent hike in petroleum prices. Empirical facts gathered reveal that the price of crude oil will remain increasing and volatile for a long time to come if there are no alternatives to cater for this rising demand from the teeming population. For instance, in Nigeria, 1 litre of kerosene is now sold for 130 as at present as against $\$ 50$ in the recent past. This is rather unaffordable for people living below poverty line in the remote areas, considering their per capital income in a day.

Sambo (2008) reported that Jathropha is a cheap and abundant alternative raw material for biodiesel production that poses no risk to global food security. The report also revealed that "the global crisis is directly linked to maize, sugarcane, cassava and other edible energy crops conversion to ethanol for biofuel because these are direct food items to a large number of the world population". In other word, the competition posed by the use of food crops as energy crop will reduce if focus is shifted to use of non-edibles like Jathropha oil crop as energy crop for biofuel production. 
Report by Haas and Mittelbach (2000) also revealed that both Jathropha plants and seeds are toxic to humans and animals due to the presence of Phorbol-esters (tumor promoter), trypsin inhibitors and lectin (plant protein that binds to carbohydrates causing blood cells to clump together, resulting in necrosis). The presence of these poisonous substances in the oil makes the oil unsuitable for use in food processing industries for production of consumables as it is non-edible. It is therefore a good raw material for biodiesel production. When the oil is processed into biodiesel, the benefits can be classified based on the economic, environmental and engine advantages. Additional benefit is in the reduction of the overdependence on fossil fuels by farmers whose power source is largely dependent on tractors with diesel engines.

Extraction of oil from both edible and non-edible oil crops using mechanical press is a widely applied process for oil extraction. Oil extraction among the bottom of pyramid people is usually done manually. Like all other manual operations, it is strenuous and time consuming. There are a lot of uncertainties on the best way to process oil seeds into oil, taking into accounts the backward circumstances in the countries involved.

In Nigeria presently, information is scanty on machines fabricated locally specifically for extraction of Jatropha oil through mechanical means. Screw geometry requirements will not make machine fabricated for oil seeds other than Jatropha suitable for Jathropha oil extraction since no oil expeller is suitable for universality of operation. Mechanical, geometric or physicochemical properties of oil seeds make most oil bearing seeds machine specific. Machine fabricated in the recent time in University of Ibadan (Unpublished thesis, Adebayo, 2010), Department of Agricultural and Environmental Engineering, was discovered to have design and operational limitations. The one fabricated in University of Lagos by Ojolo et al (2012) has power requirement (40KW) not suitable for small scale application. However, carrying out additional research using all relevant processes will assist in providing better insight on how to achieve design, process efficiencies and viabilities that have close resemblance with industrial practice.

Generally, oils are extracted by hand operated ram press, by expeller using different types of screw presses (hydraulichole, strainer press, etc.) or by solvent extraction using hexane. Based on findings by Chakrabarti and Prasa (2010), oil must be recovered through solvent extraction if the oil content of seeds or oil bearing materials is less than $30 \%$. The controversy with the report is that jatropha oil can be extracted with the expellers used for other oil crops without major challenges. An oil expeller can only be versatile for few other oil crops with similar screw geometry; it may not be suitable for universality of operation.

Some researchers have slightly modified the existing expellers used for other oils and developed one mechanical expeller comprising three components: dehuller that removes the hard-outer shell of dried seeds, the crusher that makes dehulled seeds into finer hard outer shell of dried seeds, the crusher that makes dehulled seeds into finer pieces and the oil expeller that presses the oil out of the crushed seeds (Rachimoellah et al,2008). The point is that those machines are still oil seeds specific not only because of screw geometry requirements but also because of oil point pressure (minimum pressure extraction process must attain for oil to be extracted)variation of every oil seed. More also, the initial cost of acquiring the machines may not make it suitable for small and medium scale application.

In recent years, researchers have tried ultrasonification, enzymatic extraction (shah et al, 2005), and supercritical carbon dioxide extraction (Nicolaset al, 2012) to recover Jatropha oil from its seeds. However, these are still in research phase. The conventional methods of expelling (mechanical press) and solvent extraction are still being currently used for extraction of Jatropha oil.

Shahidi (2005) reported that solvent extraction can achieve a reduction in the oil content of the press cake to less than $1 \%$. Its drawback is that it has limited economic benefit when used for small and medium scale oil extraction - it is relevant for industrial applications. Mechanical screw press is in a nutshell recommended for both small and medium scale applications.

According to Taulo(2005), some of the problems that have been encountered (in the countries where Jatropha oil machines have been fabricated and are operational) in the past are high production cost, low oil recovery when processing untreated seeds(heating and dehulling), unsmooth batch operation, heavy foots in the extracted oil, high oil content in cake fibre, problem of versatility of operation for other oil seeds with similar screw geometry for economy of scale, and comparatively high repair and maintenance cost.

The main objectives of this study are: i to design and develop an expeller for Jatropha Curcas Linn oil crop with capacity of $20 \mathrm{~kg} / \mathrm{hr}$. and oil recovery of up to $27 \%$ (\% m oil/ seeds) using a 3-phase, $7.5 \mathrm{Hp}$ gear motor assembly; ii. to test the performance of the machine developed using parameters like speed variation between 30 and 50 revolution per minutes(rpm), oil recovery, throughput capacity, varied hull fraction down to $20 \%$ from $100 \%$ and efficiency estimation of up to $80 \%$.

Principles observed(while designing the oil expeller), targeted to solve some reported existing problems with jatropha oil expeller are design of pre-treatment chamber for oil seeds before pressing to overcome the problem of unsmooth batch operation and effects of untreated seeds used in extraction process; designing the press with screw geometry specific for seeds to be processed in order to optimize oil recovery to an efficiency of over 80\%; designing to cater for variation of inputs like independent variables (hull fractions, heating time, adjustment of choke outlet) to overcome the problem of seeds pretreatment and to establish condition at which maximum oil recovery can be achieved; etc. These design principles and processing conditions were put into consideration while designing, developing and evaluating the machine to optimize jatropha oil extraction with indigenous technology.

Locally made oil mill will not only solve the problem ofhigh importation cost and overhead cost of owning one, adjustment possible with both the screw geometry and the die at choke outlet will make the machine versatile for extraction of oil from seeds with similar screw geometry like castor seeds. The choke adjuster incorporated at the peripheral to control the die prevents slippage and eventual machine seizure - it will as well aid reduction of heavy foot in the press cake. 
Findings from this endeavour will be a boon to countries with energy challenge by reducing their dependence on conventional fuel and encouraging the use of a more sustainable and renewable energy sources. Thus, this research work is really important for our nation as it will cause paradigm shift in her economy from monoculture to multifaceted level.

\section{Materials and Methods}

This section reveals the design philosophy, major component parts of the expeller, variables considered during evaluation, design calculation, experimental procedure, materials used for evaluation and method of analysis of results.

\subsection{Design Philosophy}

The design utilizes the screw pressing principle for extraction of oil from the materials like jatropha, castor and groundnut. The machine works like pressure bag. During the pressing process, oil seeds are fed in a hopper and then transported and crushed by a rotating screw (shaft with set of straight and tapered worms) in the direction of a restriction. The first step of the compression process consists of rolling, breaking, displacement and removal of air from inter-material voids. As soon as the voids diminish, the seeds start to resist the applied force through mutual contact. As the process continues, oil point pressure is reached and oil starts to find its way out of the compression chamber through the basket section of the cage assembly. Screw presses mainly differ in screw geometry, oil outlet section and press cake restriction. The commonest types are hydraulic hole and strainer press. The latter was therefore considered for development.

\subsection{Component Parts and Materials for Construction}

Major component parts are the worm assembly, the cage assembly, cooker, manual wheel drive(choke adjuster), strainer and draining trough (mild steel); reduction gear assembly; stanchion (cast iron), member frame, etc. The machine consists of the feeding chute (hopper), heating compartment (that can hold $10 \mathrm{~kg}$ of seeds at once) directly on top of the compression chamber, expelling unit, discharge units with choke adjuster, member frame (length, frame width, height and sideway thickness being $1050 \mathrm{~mm}, 500 \mathrm{~mm}, 400 \mathrm{~mm}, 320 \mathrm{~mm}$ respectively) and prime mover (medium speed gear motor assembly, 7.5Hp, 920rpm with speed ratio of 1:30) with an output speed of 30rpm. The feeding chute is pyramidal in shape and made of $1.5 \mathrm{~mm}$ gauge mild steel.

The compression chamber consists of a screw shaft of $40 \mathrm{~mm}$ diameter with detachable worms of varying pitches, basket cage (detachable) having borne (internal diameter) of $100 \mathrm{~mm}$ and outer dimension of $550 \mathrm{~mm} \times 300 \mathrm{~mm} \times 300 \mathrm{~mm}$, an in-between stanchion (mild steel $20 \mathrm{~mm}$ gauge) to hold the compression chamber assembly in place. The screw is divided into three sections; the feeding, milling and discharge sections as it tapers. The friction and pressure produced by the screw on the barrel causes the mass to heat up in addition to the preheating system directly on top of the chamber, thus facilitating oil extraction as the screw grinds and presses. Oil point pressure is easily attained with the introduction of preheating system. Ball bearing and tapered bearing were used to hold main shaft in place and as well aid effective rotation of worm assembly (quill worms, compression worms, push worm, reverse worm, collar cone, split cone and cone adjuster). Draining trough is directly under the compression chamber.

Materials for Construction are reduction gear(ratio 30:1) and medium speed electric motor(920rpm) with an output speed of 30rpm, angle iron, mild steel of varying sizes, bearings, stanchion, mild steel hollow pipe, electrodes etc. The parts were constructed in such a way that they can easily be assembled and dissembled in case there is need for repair and maintenance. Slippage and eventual machine seizure might result from power failure, overfeeding of materials into hopper and operation of machine with high speed; if machine dissemblance involves special technicality, it might be tiring using such expeller for extraction of oil. See figure 3 below for details on various component parts of the expeller.

\subsection{Design Calculations}

With measured parameters taken from hand-held equipment, equations 1, 2 and 3 below were used to calculate the three-phase input power to the loaded motor. Based on this value, motor part load was quantified by comparing measured input power under load to the power required when the motor operates at rated capacity. The relationship is as shown in equation 3. (Baldor Electric Company, 2007).

\subsubsection{Input Power Measurement}

$\mathrm{Pi}=\underline{\mathrm{HP} \times \mathrm{Vx} \mathrm{I} \times \mathrm{PF} \times \sqrt{3}}$.

$1000 \quad \mathrm{Pi}=$ Three-phase power in $\mathrm{kW}, \mathrm{V}=$ r.m.s. voltage, mean line-to-line of 3 phases

$\mathrm{I}=$ Current, $\mathrm{PF}=$ Power factor, $\mathrm{HP}=$ Horse power of the electric motor

Assume $\mathrm{PF}=0.8, \mathrm{HP}=7.5 \mathrm{HP}$. From the rule of Thumb (see appendix for details), I =2.5A, V =230v ( 3 phase motor).

$\mathrm{P}_{\mathrm{i}}=\underline{230 \times 0.7 \times 2.5 \times 7.5 \times \sqrt{3}}$

$$
1000 \quad P_{i}=5.23 \mathrm{~kW}
$$

Pir $=$ HP $\times 0.7457$

$\eta f l$

Pir = Input power at full-rated load in $\mathrm{kW}, \mathrm{hp}=$ Nameplate rated horsepower

$\eta \mathrm{fl}=$ Efficiency at full-rated load (it is around $75 \%$ for standard electric motor)

Pir $=7.5 \times 0.7457, \quad(1 \mathrm{HP}=0.7457 \mathrm{KW})$

$$
0.75=7.457 \mathrm{KW}
$$

Load $=\operatorname{Pi} \times 100 \%$

Pir 
Load = Output power as a \% of rated power

Since Load $=$ Pi $\times 100 /$ Pir

Load therefore $=5.23 \times \frac{100}{7.457}=70.1 \%$

Hence, actual output power, $\mathrm{P}=\mathrm{Load} \times 7.5 \mathrm{Hp}=0.701 \times 7.5$

$\mathrm{P}=5.26 \mathrm{HP}=5.26 \times 0.7547 \mathrm{KW}=3.97 \mathrm{kw}$

\subsubsection{Main Shaft Design}

The power P supplied by the gear motor arrangement can be used to determine torque (torsional moment), pure torsional stress and force of the main shaft.

$\mathrm{P}=2 \pi \mathrm{NT}$

(IJETS|www.techsciencepub.com/ ijets) 60

Where $\mathrm{N}=$ speed of the main shaft. $\quad \mathrm{T}=$ torque, $\quad$ It implies that $\mathrm{P}=\underline{2 \times \pi \times 30 \times \mathrm{T}}$

$\mathrm{T}=\underline{3.97 \times 10^{3} \times 60}$

$$
2 \times \pi \times 30=1263 \mathrm{Nm}
$$

$\mathrm{T}=\underline{\pi \mathrm{d}^{3} \tau}$

16 (IJETS|www.techsciencepub.com/ ijets)

Where $\mathrm{d}=$ diameter of shaft, and $\tau=$ shear stress.From equation five,

$\tau=\underline{\mathrm{T}} \times 16$.

$\pi \times \mathrm{d}^{3}$

$\mathrm{d}=40 \mathrm{~mm}, \tau=\underline{1263 \times 16}$

$\pi \times(0.04)^{3}=100.506 \times 10^{6} \mathrm{~N} / \mathrm{m}^{2}$.

Therefore, $\tau=100.51 \mathrm{~N} / \mathrm{mm}^{2}$

\subsubsection{Worm Shaft Design}

In an expeller, the design of the screw has basic importance as it determines the performance efficiency. Literature survey reveals that there is scanty information describing the effect of a specific configuration on extraction process. Scanty work appears to have been done by manufacturing industries using empirical approach. A more rigorous scientific approach is thus required to predict more accurately, the results of a particular worm configuration (Taulo J. 2005). Screw Configuration (configuration of worms on the main shaft) used in the expeller design of this research work is as in table 1 below.

\begin{tabular}{|c|c|c|c|c|c|c|}
\hline Parameter & $\begin{array}{l}\text { Cool } \\
\text { Worm }\end{array}$ & Push Worms & $\begin{array}{l}\text { Reverse } \\
\text { wormworm }\end{array}$ & Push & $\begin{array}{l}\text { Straight } \\
\text { collar }\end{array}$ & $\begin{array}{c}\text { Tapered } \\
\text { collar }\end{array}$ \\
\hline Position of worm & 1 & $\begin{array}{llll}2 & 3 & 4 & 5\end{array}$ & 6 & 7 & 8 & 9 \\
\hline $\begin{array}{l}\text { Length of worm } \\
(\mathrm{mm})\end{array}$ & 200 & $\begin{array}{llll}70 & 70 & 70 & 70\end{array}$ & 70 & 75 & 75 & $130 \quad 70$ \\
\hline $\begin{array}{l}\text { Screw hub diam. } \\
(\mathrm{mm})\end{array}$ & 40 & $404040 \quad 40$ & 40 & 40 & 40 & 40 \\
\hline
\end{tabular}

Table 1 Screw Configuration (Configuration of Worms on the Main Shaft) Note: Spacer or Retail Collar Starts from Second Worm (19mm Each)

2.3.4. Compression Chamber Design

$\mathrm{T}=\mathrm{Fxr}$

Where $\mathrm{T}=$ torque, $\mathrm{F}=$ force required to drive the shaft and $\mathrm{r}=$ radius of shaft

$\mathrm{F}=\mathrm{T} / \mathrm{r} \quad \mathrm{r}=$ radius of the shaft

$=\underline{1263 \times 10^{3}}$

$\frac{1263 \times 103}{20}=63.151 \mathrm{kN}$

Pir $=\frac{F}{A}=\frac{F}{\pi \times D(D-d h)}$

$$
=63.151 \mathrm{kN}
$$

Where $\mathrm{D}$ is chamber inner diameter. If pressure, Pr required to extract oil from Jatropha seed (oil point pressure) is taken as $140 \mathrm{~kg} / \mathrm{cm}^{2}$ (Harmanto et al, 2007).

$\mathrm{P}_{\mathrm{r}}=140 \mathrm{~kg} / \mathrm{cm}^{2}=140 \times 10(\mathrm{~N})$ $100 \mathrm{xcm}^{2}$

$\mathrm{P}_{\mathrm{r}}=14 \mathrm{~N} / \mathrm{mm}^{2} . \quad$ Since $\mathrm{F}=63.15 \times 10^{3}$

$\mathrm{A}=63.15 \times 10^{3}, \mathrm{~A}=\underline{63.15 \times 10^{3}}$ 


$$
D\left(D-d_{h}\right)=\frac{63.15 \times 10^{3}}{\Pi \times 14}
$$

$\mathrm{D}^{2}-\mathrm{Dd}_{\mathrm{h}}-1436=0$

$\mathrm{d}_{\mathrm{h}}=$ worms core diameter. For diameter $\mathrm{d}_{\mathrm{h}}=85 \mathrm{~mm}$

$D^{2}-85 D-1436=0 \quad D=\frac{-b \pm \sqrt{b^{2}-4 a c}}{2 a}$.

$\mathrm{D}=\frac{85 \pm\left\{(-85)^{2}-4 \times 1 \mathrm{x}-1436\right\}}{2 \mathrm{x} 1}$

$\mathrm{D}=\frac{85 \pm \sqrt{ }(12969)}{2}$

$$
\mathrm{D}=99.5 \text { or }-14.5
$$

$\mathrm{D}=99.5 \mathrm{~mm} \quad \mathrm{D} \approx 100 \mathrm{~mm}$. Note: the diameter with negative value is discarded

Hence, diameter of inner chamber can be taken as $\mathrm{D}=100 \mathrm{~mm}$.

According to Adebayo (2010), bulk density of Jatropha seed at 5.85\% moisture content is averagely $428 \mathrm{~kg} / \mathrm{m}^{3}$.

\subsubsection{Shear Force and Bending Moment Calculations}

Weight of main shaft, $W_{s}=50 N$. Also, weight $W_{j}$ of materials in the hopper section is $40 \mathrm{~N}$.

Assume weight of section of worms on the main shaft to be $\mathrm{W}_{\mathrm{w}}=80 \mathrm{~N}$ altogether. Therefore, different forces acting on the main shaft are as analyzed below in figure 1 .

Shear force and bending moment diagram are as in figure 2 below .

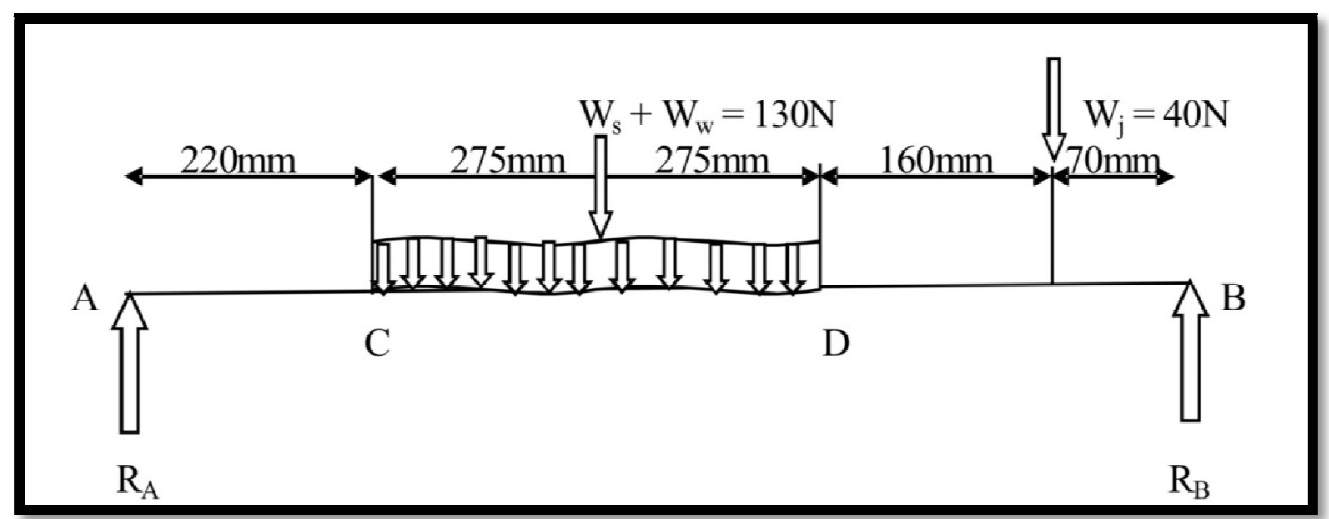

Figure 1 Force Analysis of the Oil Expeller

$R_{A}$ and $R_{B}$ are Reactions at the Two Bearing Sections

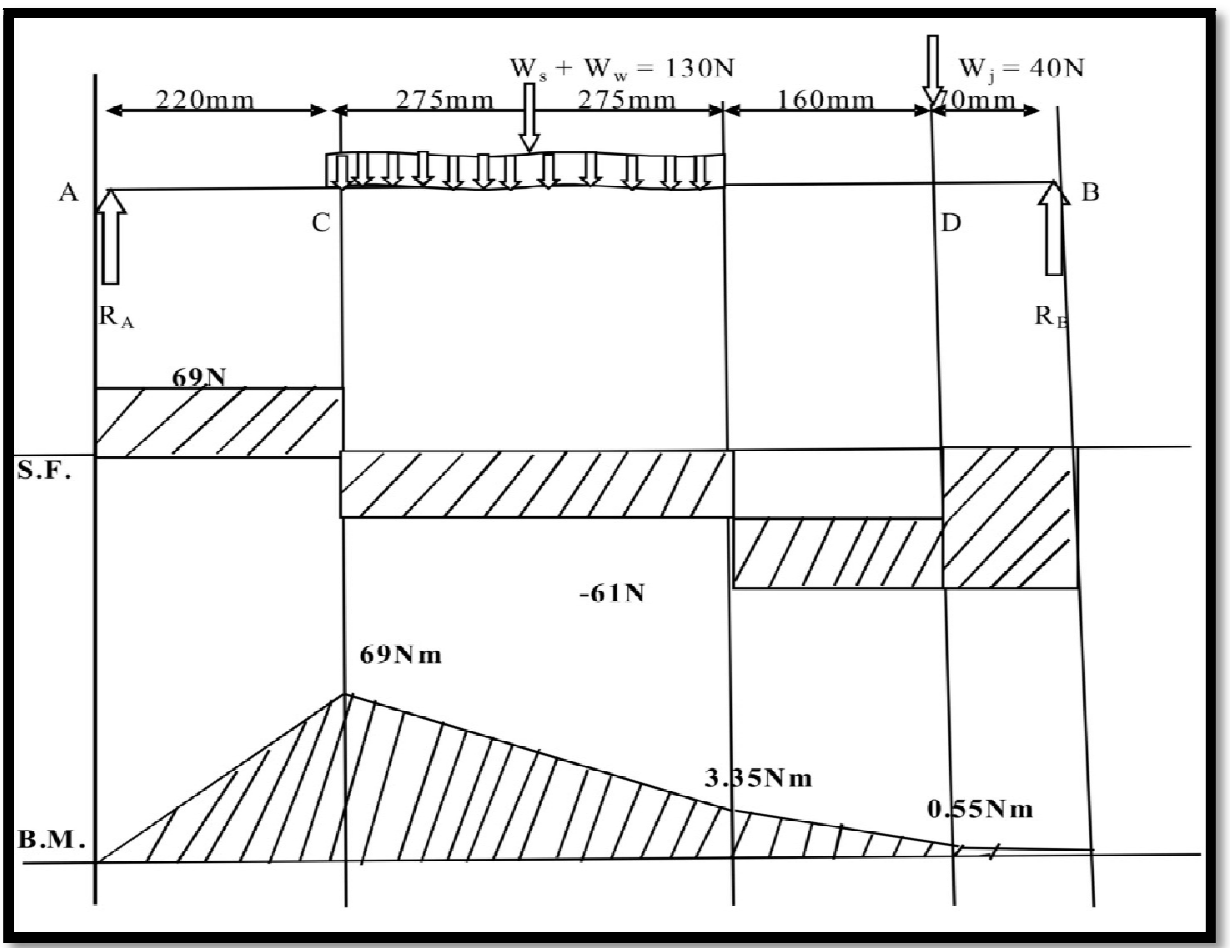

Figure 2: Shear Force and Bending Moment Diagram

Note: From the Diagram, it can be inferred that Maximum Bending Moment is $69 \mathrm{Nm}$

2.3.5.1. Shear Force Calculations

$\mathrm{R}_{\mathrm{A}}+\mathrm{R}_{\mathrm{B}}=130+40=190 \mathrm{~N}$-upward forces equal downward forces 
$\Sigma \mathrm{M}=0$ - taking moment about point $\mathrm{B}$ on the force analysis diagram of the main shaft above,

$\mathrm{R}_{\mathrm{A}} \mathrm{x} \frac{(220+550+160+70)}{1000}=130 \frac{(275+160+70)}{1000}+\underline{40 \times 70}$

$\mathrm{R}_{\mathrm{A}}=68.45 \approx 69 \mathrm{~N}, \quad \mathrm{R}_{\mathrm{B}}=190-69=121 \mathrm{~N}$.

2.3.5.2. Bending Moment Calculations

Taking moment about a fixed axis B:

1. At point $\mathrm{A} ; \mathrm{R}_{\mathrm{A}} \mathrm{x}(220 \times 275 \times 275 \times 160 \times 70) / 1000$

$=69 \times 1000=69 \mathrm{Nm}$

2. At point C; $\quad \mathrm{R}_{\mathrm{A}} \underline{\mathrm{x} 1000}-\underline{130 \times(275+160+70)}$

$=69-65.65=3.35 \mathrm{Nm}$

3. At point $D ; R_{A} \times \frac{1000}{1000}-65.65-\frac{40 \times 70}{1000}$

$=69-65.65-2.8=0.55 \mathrm{Nm}$.

\subsection{Experimental Procedure}

The description of a typical experiment was used to explain the experimental procedure. The seeds were preheated to varying temperatures with heating times of cold pressing, 10, 20 and 30 minutes respectively. After preheating, seeds or press cake (for double pass) were released into the feeder/ hopper on the right side of the press shown in plates 1 and 3 below. The roaster incorporated in the design aids continuous operation of the expeller as against batch process in common practice. There will definitely be little variations in the operation of the machine at the start as it takes some time for the process to stabilize. Stepwise reduction in the clearance between the worms' arrangement and the cylindrical barrel brings about pressure increase. Increased pressure generated therefore compact the material to squeeze out oil.

The expressed oil flows out of the press through the slots provided on the periphery of the barrel. Crude oil is collected at the oil outlet and press cake exits the machine at the adjustable cone section. The weight of oil extracted is then recorded using digital measuring scale (see Figure 10 and Appendix 3). In addition, the time required for a batch to pass through the press was measured. It was difficult to determine the instant at which the pressing finished, therefore the time measurement was started when the pressure showed a steep increase after seeds were fed and stopped once pressure drastically declined while the press was almost empty in order to generate comparable results. After leaving the oil to settle for a week, relative amount of foots in the crude oil could be determined. For experiment with double pass, the press cake is fed back into the press and the whole process repeated for a second time.

\subsection{Materials for Evaluation and Variables Considered}

Materials used for machine evaluation are Jatropha seeds, Castor seeds, Groundnut seeds, Sensitive measuring scale, stop watch and recording materials. Variables considered during evaluation are dependent variables like oil recovery, throughput capacity and efficiency. Independent variables considered are shaft speed, restriction size, hull fraction, cooking time and moisture content.

\subsection{Method of Analysis of Results}

Measurement of oil mass method (percentage of the ratio of mass of oil extracted to initial oil content of the kernel processed) was used for efficiency determination. Correlation (product moment method) and Regression (least square method) were used as statistical instrument for result analysis. Correlation coefficient, $r$ is as given in equation 11 below. Null hypothesis is Ho: $0.5 \leq r \leq 1$; whilealternative hypothesis is $\mathrm{H}_{1}: \mathrm{r}<0.5$. For Ho in the range of values stated above, it means there is a strong relationship between the dependent variable and independent variable. If the correlation coefficient is not within acceptable region, alternative hypothesis is accepted. The implication of this is that the relationship between them is weak.

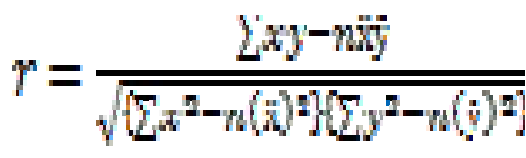

...(13)

$\mathrm{a}=\overline{\mathrm{y}}-\mathrm{b} \ddot{\mathrm{x}}$ (11),

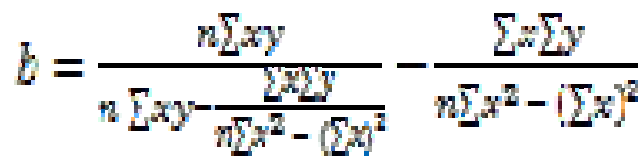

Using equations 12 and 13, regression line " $\mathrm{y}=\mathrm{bx}+\mathrm{a}$ " can be determined.

Relationship between the dependent variables and the independent variables was established through the statistical instrument (see the annex of this report for details of the calculation and table 9 for summary of the relationship). Physico-chemical characteristic of the oil expelled was carried out using standard scientific laboratory. The designed machine is as shown in figure 3 below. 


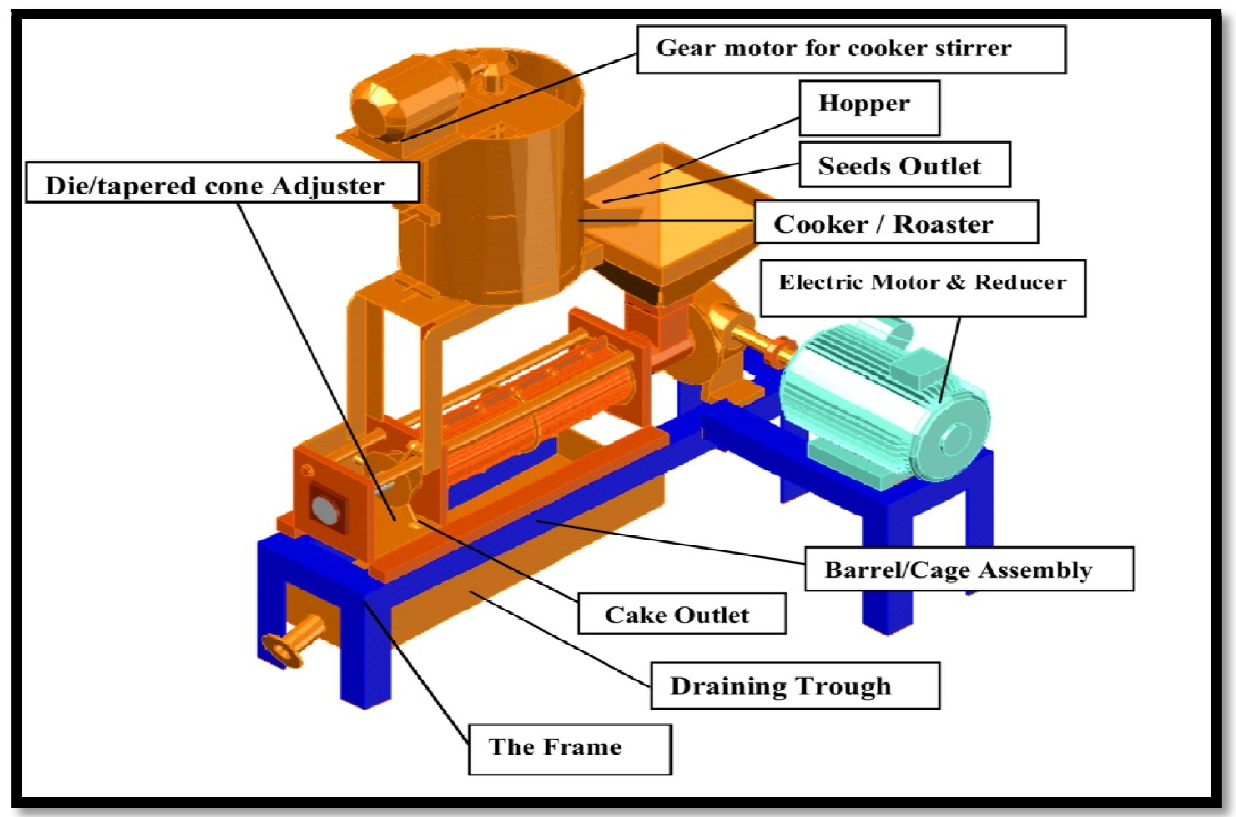

Figure 3 Pictorial View of the Machine

- Gear motor for cooker stirrer

- Hopper

- Seeds Outlet

- Cooker / Roaster

- Electric Motor \& Reducer

- Barrel/ Cage Assembl

- Cake Outlet

- Draining Trough

- The Frame

- oil outlet

- Die/ tapered cone Adjuster

\section{Results and Discussion}

Screw type oil presses are advanced oil processing machinery characterized by their high oil output rate with good quality, simple design, easy to use and continuous operation. Like in any manufacturing company, after a new product has been developed, it has to be tested to confirm whether its performance conformed to its design objectives. The test also assists in determining how effective it is in carrying out expected operation. This same industrial principle was adopted for the newly constructed machine in terms of oil recovery, efficiency and throughput capacity of the expeller. All these parameters were established during testing. The pictures of the newly developed oil expeller are as in plates 1 and 3 below. Materials evaluated, products and bye products of evaluation are as in figure 10 below.

\subsection{Results}

The results of parameters tested (suitability of the machine for other oil crops, dependent variables like throughput capacity, efficiency and oil recovery using varied parameters like restriction size, heating time, hull fraction, speed, etc. ) are as in tables 2 to 7 below. The charts of the different variations observed are as in figures $4-9$ below.

\begin{tabular}{|c|c|c|c|c|}
\hline Test & $\begin{array}{c}\text { Weight of Groundnut } \\
\text { Seed Processed (kg) }\end{array}$ & $\begin{array}{c}\text { Weight of Oil } \\
\text { Extracted (Kg) }\end{array}$ & $\begin{array}{c}\text { Oil Recovery } \\
\text { (m\% oil/ seed) }\end{array}$ & $\begin{array}{c}\text { Efficiency } \\
\text { (\% oil/ oil) }\end{array}$ \\
\hline 1 & $2.0 \mathrm{~kg}$ seeds & 0.563 & 28.15 & 70.36 \\
\hline 2 & $2.0 \mathrm{~kg}$ seeds & 0.579 & 28.93 & 72.38 \\
\hline 3 & $2.0 \mathrm{~kg}$ seeds & 0.581 & 29.05 & 72.63 \\
\hline
\end{tabular}

Table 2: Determination of Suitability of Jatropha Press for Groundnut Oil Extraction Using

'Measurement of Oil Mass Method' (With Single Pass) - at 20 Min. Heating Time and Hull Fraction of 40\%, Groundnut Seeds

Oil recovery is an equivalence of the efficiency of the machine. Initial oil content of the seed is $40 \%$ of total weight. Expected oil recovery for $2 \mathrm{~kg}$ seed is $0.8 \mathrm{~kg}$. From table 2 above, average oil recovered for single pass is approximately $72 \%$. It was observed that the screw geometry tends to favour groundnut oil extraction than other oil seeds (Castor and 
Jatropha) considered (see tables 3 - 7), since the extraction process only requires single pass for the efficiency of the machine to rise to $70 \%$ and with double pass, it peaked to over $80 \%$. The machine is therefore suitable for groundnut oil extraction - See figure 4 below for graph of relationship between efficiency and hull fraction of groundnut oil at single pass with varied hull fraction of up to $60 \%$.

\begin{tabular}{|c|c|c|c|c|}
\hline Test & $\begin{array}{c}\text { Weight of Groundnut } \\
\text { Seed Processed (kg) }\end{array}$ & $\begin{array}{c}\text { Weight of Oil } \\
\text { Extracted (Kg) }\end{array}$ & $\begin{array}{c}\text { Oil Recovery } \\
\text { (m\% oil/ seed) }\end{array}$ & $\begin{array}{c}\text { Efficiency } \\
\text { (\% oil/ oil) }\end{array}$ \\
\hline 1 & $2.0 \mathrm{~kg}$ seeds $+40 \%$ shell & .413 & 20.66 & 51.65 \\
\hline 2 & $2.0 \mathrm{~kg}$ seeds $+40 \%$ shell & 0.422 & 21.10 & 52.76 \\
\hline 3 & $2.0 \mathrm{~kg}$ seeds $+40 \%$ shell & 0.425 & 21.24 & 53.09 \\
\hline
\end{tabular}

Table 3: Determination of Suitability of Jatropha Press for Castor Oil Extraction Using 'Measurement of Oil Mass Method' (With Single Pass) - at 20min Heating Time

Initial oil content of the seeds in table 3 is $40 \%$ of total weight. Expected oil recovery for $2 \mathrm{~kg}$ seed is $0.8 \mathrm{~kg}$. Average oil recovered for single pass is approximately $52.5 \%$. With double pass, the efficiency rose to $80 \%$. The graph of the relationship between efficiency and hull fraction of castor oil (of up to 40\%) in figure 5 below serves to further buttress the press suitability for Castor oil extraction. Perhaps, if the hull fraction is increased beyond $40 \%$ and minor adjustment made on the screw geometry, the efficiency may rise beyond $52.5 \%$ at single pass to over $70 \%$.

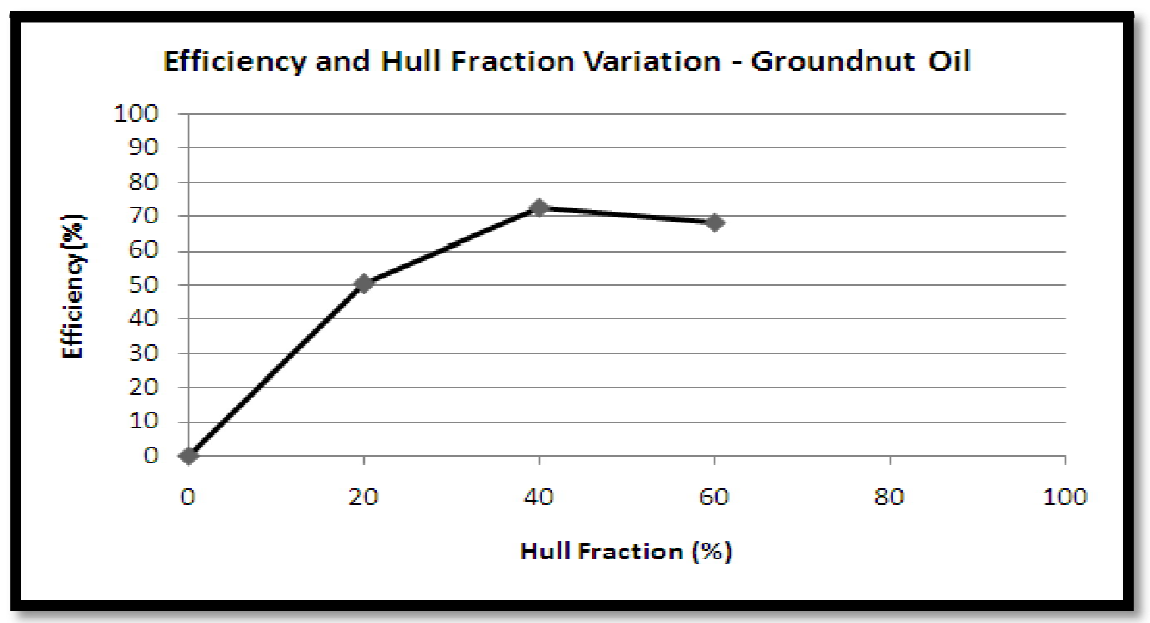

Figure 4: Relationship between Efficiency and Hull Fraction of Groundnut Seeds

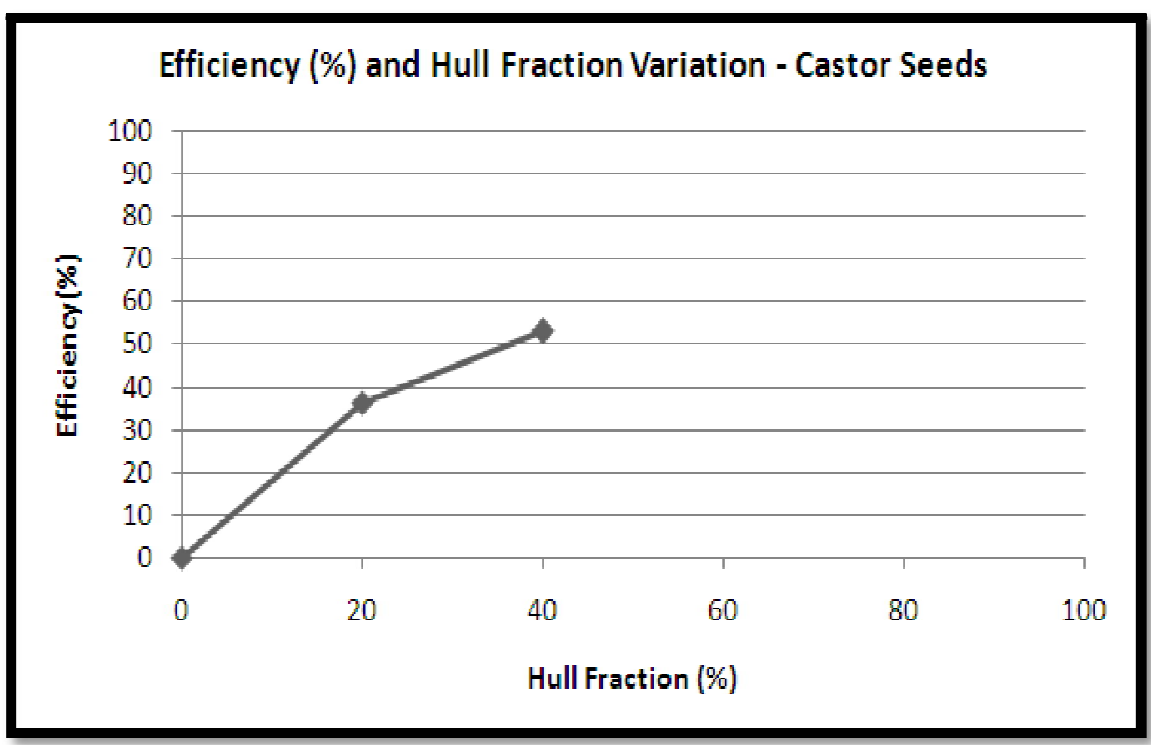

Figure 5: Relationships between Efficiency and Hull Fraction of Castor Seeds 


\begin{tabular}{|c|l|c|c|c|}
\hline Test & $\begin{array}{c}\text { Initial weight of Jatropha } \\
\text { Seeds (Kernel + Hull, kg) }\end{array}$ & $\begin{array}{c}\text { Weight of Oil } \\
\text { Extracted (Kg) }\end{array}$ & $\begin{array}{c}\text { Oil Recovery } \\
\text { (m\% oil/ seed) }\end{array}$ & $\begin{array}{c}\text { Efficiency } \\
\text { (\% oil/ oil) }\end{array}$ \\
\hline 1 & $1.5 \mathrm{~kg}$ kernel +1.5kg hull & 0.359 & 23.93 & 79.67 \\
\hline 2 & $1.5 \mathrm{~kg}$ kernel +1.5kg hull & 0.358 & 23.86 & 79.84 \\
\hline 3 & $1.5 \mathrm{~kg}$ kernel +1.5kg hull & 0.363 & 24.20 & 80.56 \\
\hline
\end{tabular}

Table 4: Determination of Oil Recovery Using Measurement of Oil Mass Method (With Double Pass) - At 4mm Choke Opening

Note: Oil Recovery Is an Equivalence of the Efficiency of the Machine Average Oil Recovery for Double Pass Is $80.02 \%$

Table 4 above reveals the efficiency of the machine (using jathropha seeds) averagely as $80.02 \%$ with double pass. The hull fraction of $100 \%$ used may be responsible for the efficiency drop recorded with the machine or even operational limit. More also, minor adjustment has to be made on the screw geometry to record maximum oil recovery. The chart in figure 6 below shows the efficiency with double pass. The efficiency drops as hull fraction increased beyond 80\%.

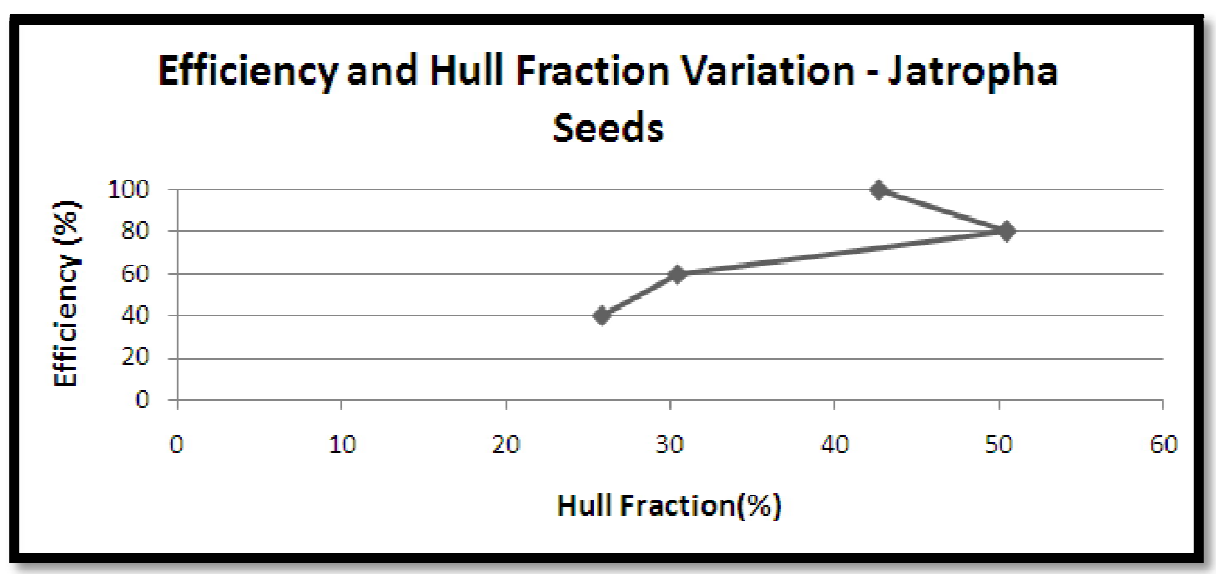

Figure 6: Relationships between Efficiency and Hull Fraction of Jatropha Seeds

\begin{tabular}{|c|c|c|c|c|}
\hline Test & $\begin{array}{c}\text { Weight of Seeds (kg) \& } \\
\text { Hull Fraction Processed }\end{array}$ & $\begin{array}{c}\text { Time for oil } \\
\text { extraction (min.) }\end{array}$ & $\begin{array}{c}\text { Throughput } \\
\text { (kg/ hr) }\end{array}$ & $\begin{array}{c}\text { Oil recovery (\% oil/ seed) } \\
\text { (Single Pass) }\end{array}$ \\
\hline \multicolumn{5}{|c|}{ At 4mm Choke Opening } \\
\hline 1 & 4.0 & 15 & 16.00 & 12.22 \\
2 & 4.0 & 14 & 17.14 & 12.34 \\
3 & 4.0 & 14 & 17.14 & 12.53 \\
\hline \multicolumn{5}{|c|}{ At 6mm Choke Opening } \\
\hline 1 & 4.0 & 15 & 16.00 & 9.22 \\
2 & 4.0 & 14 & 17.14 & 9.36 \\
\hline \multicolumn{5}{|c|}{ At 8mm Choke Opening } \\
\hline 1 & 4.0 & 14 & 18.46 & 7.00 \\
3 & 4.0 & 14 & 17.14 & 7.15 \\
\hline
\end{tabular}

Table 5: Throughput Capacity of the Machine at Varied Restriction Level (Cold Pressing)

From table 5, average time used to run $4 \mathrm{~kg}$ of seeds is 14 minutes. The choke openings varied were 4,6 and $8 \mathrm{~mm}$ respectively. It was observed that the choke adjustment has slight effect on throughput capacity of the expeller. Machine throughput is therefore $17.18 \mathrm{~kg} / \mathrm{hr}$ averagely. The oil recovery was observed to be maximum $(12.53 \%)$ with $4 \mathrm{~mm}$ choke opening. When the process was tried with $2 \mathrm{~mm}$ opening, machine eventual seizure resulted. See figure 7 below for further illustration on the relationship. 


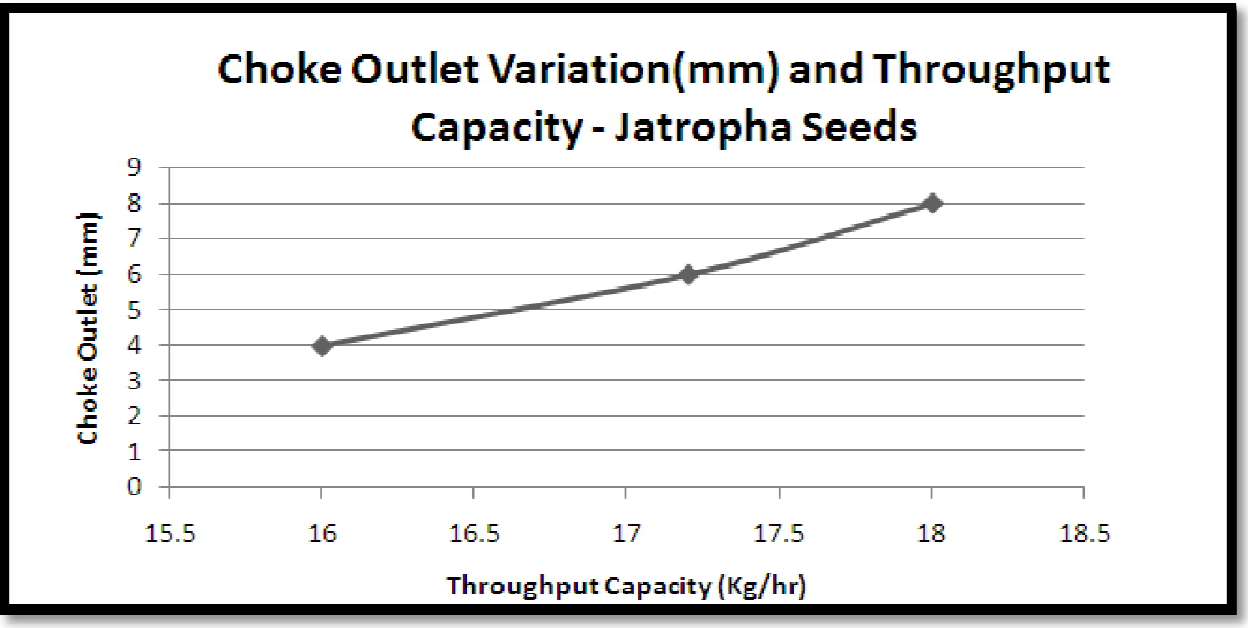

Figure 7: Relationship between Choke Clearance and Throughput Capacity of Jatropha Seeds

\begin{tabular}{|c|c|c|c|c|}
\hline Test & $\begin{array}{c}\text { Initial Weight of Jatropha } \\
\text { Seeds (Kernel + Hull, kg) }\end{array}$ & $\begin{array}{c}\text { Estimated Weight } \\
\text { of Oil extracted (kg) }\end{array}$ & $\begin{array}{c}\text { Oil recovery } \\
\text { (m \% oil/ seed) }\end{array}$ & $\begin{array}{c}\text { Efficiency } \\
\text { (\% oil/ oil) }\end{array}$ \\
\hline 1 a. & 1.5kg kernel +0.6kg Hull (40 \%) & 0.113 & 7.55 & 25.11 \\
b. & 1.5kg kernel +0.6kg Hull (40\%) & 0.116 & 7.73 & 25.77 \\
\hline 2 a. & $1.5 \mathrm{~kg}$ kernel +0.9kg Hull (60 \%) & 0.117 & 7.80 & 26.00 \\
b. & $1.5 \mathrm{~kg}$ kernel +0.9kg Hull (60 \%) & 0.119 & 7.93 & 26.42 \\
\hline 3 a. & $1.5 \mathrm{~kg}$ kernel +1.2kg Hull (80 \%) & 0.201 & 13.40 & 55.67 \\
b. & $1.5 \mathrm{~kg}$ kernel +1.2kg Hull (80 \%) & 0.209 & 13.93 & 4.02 \\
\hline 4 a. & 1.5kg kernel +1.5kg Hull (100\%) & 0.180 & 12.00 & 42.00 \\
b. & 1.5kg kernel +1.5kg Hull (100\%) & 0.191 & 12.73 & \\
\hline
\end{tabular}

Table 6: Determination of Oil Recovery and Efficiency Using "Measurement of Oil Mass Method' at Varied Hull Fraction (With Single Pass), Cold Press and Choke Opening of $4 \mathrm{Mm}$ - (Jatropha Seeds)

Initial oil content of the seeds in table 6 is $30.01 \%$ of total weight of the Kernel $(0.45 \mathrm{~kg})$. Kernel weight used was $1.5 \mathrm{~kg}$. Efficiency is maximum at $80 \%$ hull fraction and slightly above with single pass. All these were performed at cold press. Perhaps, if the seeds were preheated before running the experiment with varied hull fraction, the efficiency might rise beyond that. It was observed that running the machine with $100 \%$ kernel (no hull fraction) resulted in little or no oil recovery - only paste were observed coming out of the machine. The implication is that certain percentage of hull fraction is needed to make the pressure requirement peak up to oil point pressure.

\begin{tabular}{|c|c|c|c|c|}
\hline Test & $\begin{array}{l}\text { Initial Weight of Jatropha } \\
\text { Seeds (Kernel + Hull, kg) }\end{array}$ & $\begin{array}{l}\text { Weight of Oil } \\
\text { Extracted }(\mathrm{Kg})\end{array}$ & $\begin{array}{c}\text { Oil recovery } \\
\text { (m \% oil/ seed) }\end{array}$ & $\begin{array}{l}\text { Efficiency } \\
\text { (\% oil/ oil) }\end{array}$ \\
\hline \multicolumn{5}{|c|}{ Cold Pressing } \\
\hline $1 \mathrm{a}$. & $1.25 \mathrm{~kg}$ kernel $+1.25 \mathrm{~kg}$ hull & 0.105 & 8.40 & 28.00 \\
\hline b. & $1.25 \mathrm{~kg}$ kernel $+1.25 \mathrm{~kg}$ hull & 0.110 & 8.80 & 29.32 \\
\hline \multicolumn{5}{|c|}{10 minutes heating Time } \\
\hline $2 \mathrm{a}$. & $1.25 \mathrm{~kg}$ kernel $+1.25 \mathrm{~kg}$ hull & 0.119 & 9.52 & 31.73 \\
\hline b. & $1.25 \mathrm{~kg}$ kernel $+1.25 \mathrm{~kg}$ hull & 0.122 & 9.76 & 32.52 \\
\hline \multicolumn{5}{|c|}{20 minutes heating Time } \\
\hline $3 \mathrm{a}$. & $1.25 \mathrm{~kg}$ kernel $+1.25 \mathrm{~kg}$ hull & 0.209 & 16.72 & 55.73 \\
\hline b. & $1.25 \mathrm{~kg}$ kernel $+1.25 \mathrm{~kg}$ hull & 0.205 & 16.40 & 54.65 \\
\hline \multicolumn{5}{|c|}{30 minutes heating Time } \\
\hline $4 \mathrm{a}$. & $1.25 \mathrm{~kg}$ kernel $+1.25 \mathrm{~kg}$ hull & 0.189 & 15.12 & 49.40 \\
\hline b. & $1.25 \mathrm{~kg}$ kernel $+1.25 \mathrm{~kg}$ hull & 0.178 & 14.24 & 47.45 \\
\hline
\end{tabular}

Table 7: Determination of Effect of Heating Time on Oil Recovery (With Single Pass) at Heating Time up to 30min.\& Choke Opening of $4 \mathrm{~mm}$ - (Jatropha Seeds) 
Initial oil content of the seeds processed in table 7 is $30.01 \%$. Weight of oil in $1.25 \mathrm{~kg}$ of kernel processed is $0.375 \mathrm{~kg}$. Maximum efficiency estimated for the process is maximum (55.73) at 20minutes heating time with single pass. It was observed that the efficiency began to reduce as the heating time rose beyond 20 minutes. Part of the oil evaporated during extraction process. The low efficiency is traceable to high temperature value of extraction process. It is therefore suggested that extraction process should not be carried out beyond pre-treatment value of $20^{\circ} \mathrm{C}$. See figure 8 below on how heating time affects the efficiency. Below (table 8) is an overview of the tested parameters for the expeller.

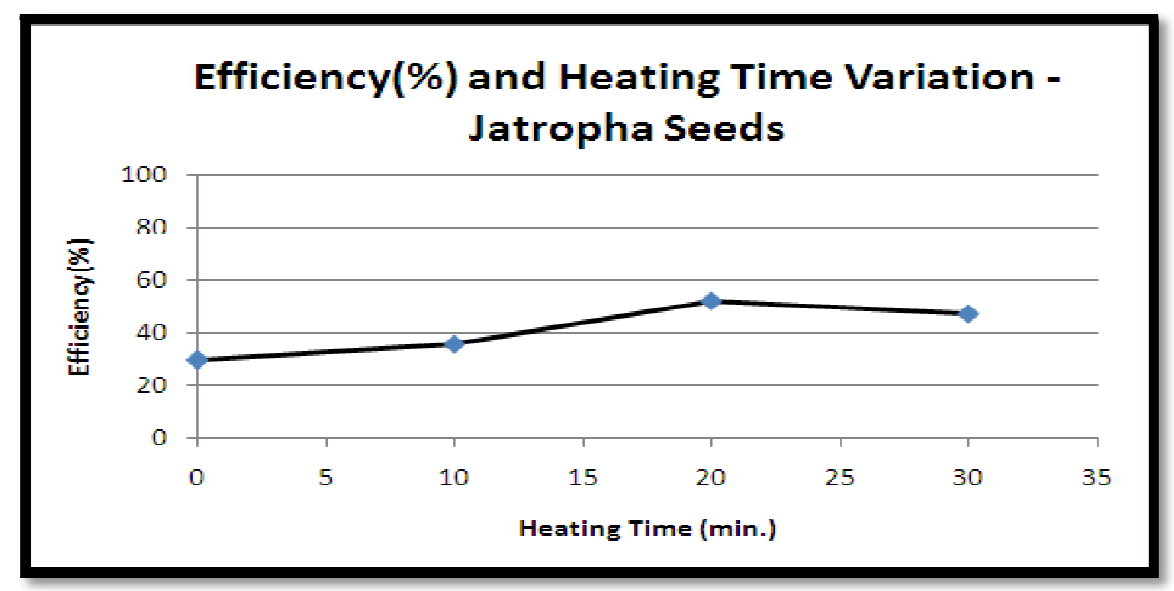

Figure 8: Relationships between Efficiency and Heating Time of Jatropha seeds

\begin{tabular}{|c|c|}
\hline \multicolumn{2}{|c|}{ Press Settings } \\
\hline RPM & 30 \& 50rpm \\
Number of Pass & Single \& Double Pass \\
Restriction & $4,6 \& 8 \mathrm{~mm}$ \\
De-hulling/ Hull fraction & $40,60,80 \& 100 \%$ \\
Number of pass & Single \& Double pass \\
Seed pre-treatments & cold press, 10, 20 and 30 min. of heating \\
Moisture content & $7.7 \% \mathrm{db}$ \\
\hline
\end{tabular}

Table 8: Overview of the Tested Variables for the Press

\begin{tabular}{|c|c|c|c|c|c|}
\hline $\mathbf{S} / \mathbf{N}$ & $\begin{array}{c}\text { Dependent } \\
\text { Variable }\end{array}$ & $\begin{array}{c}\text { Independent } \\
\text { Variable }\end{array}$ & $\begin{array}{l}\text { Resulting } \\
\text { Equation }\end{array}$ & Null Hypothesis, $r$ & Inference \\
\hline 1 & Efficiency & Hull Fraction & $y=0.33 x+11.5$ & $\begin{array}{c}\mathrm{r}=\frac{667.2}{\sqrt{\{2000 \times 318.57\}}}=0.8359 \\
\approx 0.84\end{array}$ & $\begin{array}{c}\text { Strong correlation, } \\
\text { Ho is therefore } \\
\text { accepted }\end{array}$ \\
\hline 2 & Efficiency & Heating Time & $y=0.8 x+28.23$ & $\begin{array}{c}\mathrm{r}=\frac{399.2}{\sqrt{\{500 \times 394.5\}}}= \\
0.8988 \approx 0.90\end{array}$ & $\begin{array}{c}\text { Strong correlation, } \\
\text { Ho is therefore } \\
\text { accepted }\end{array}$ \\
\hline 3 & $\begin{array}{c}\text { Throughput } \\
\text { Capacity }\end{array}$ & $\begin{array}{c}\text { Choke } \\
\text { Clearance }\end{array}$ & $\begin{array}{c}y=0.205 x+ \\
15.95\end{array}$ & $r=\frac{1.64}{\sqrt{\{8 \times 0.343\}}}=0.99$ & $\begin{array}{c}\text { Strong correlation, } \\
\text { Ho is therefore } \\
\text { accepted }\end{array}$ \\
\hline
\end{tabular}

Table 9: Relationship between Dependent Variables and Independent Variables

\subsection{Discussion}

Solvent extraction was used to determine the initial oil content of the oil seeds (Jatropha, Castor and Groundnut) used. The initial oil content of Jatropha, Castor and Groundnut seeds are 30.01\%, 40\% and 40\% respectively (see Appendix 1) at moisture content (MC) of $7.21 \%$ dry basis (db.). Table 2, 3 and 4 above describe the results of groundnut, castor and Jatropha, pressing in the sequence as the hull content was varied at some of the processes. Details of the calculation can be found in the annex of this report. The calculation is meant to provide a relative comparison of efficiency of the varied parameters so as to establish the parameter that has highest positive influence on efficiency.

Pressing partly de-hulled Jatropha seeds results in lower amount of heavy foot (traces of cake particles in the oil). However, due to the fact that the fibre content of the entire seeds is only partly determined by the hull fractions, a decrease of the hull content will result only in a small reduction of this heavy foot. Depending on the defined limitations, the strainer press throughput was evaluated averagely as $17 \mathrm{~kg} / \mathrm{hr}$. It was observed that the clearance for cake at the choke outlet had little influence on the machine throughput capacity and high influence on machine efficiency. As the clearance increases from $4 \mathrm{~mm}$ upward, the machine efficiency reduces (see table 5 for details). Maximum efficiency of 55 $\%$ was recorded at $80 \%$ hull fraction with single pass and best heating time of 20 minutes (see table 6 ). With double pass, the efficiency rose to an average value of $80.02 \%$. This compares favourably with existing records on oil expellers (Beerin, 2007). Oil recovery is an equivalence of machine efficiency - for that condition, it was estimated as 24.20 (\% m oil/ seed). 
In confirming its suitability for other oil crops, variables like shell fraction of $40 \%$ (and above with single pass) gave efficiency of the machine for groundnut oil seeds as $72.03 \%$ (see table 2 for details). For castor, the efficiency was estimated as $52.5 \%$ (see table 3 for details). Important to note is the fact that the strainer press requires dual passing for Jatrotha and castor seeds for the machine efficiency to rise to comparable level unlike single passing with groundnut seeds. The tests conducted during this research showed close resemblance with industrial practice. Taking into consideration all the test results, optimal oil recovery is expected at lowest possible moisture content of $7 \%$, cooking time of about 20 minutes, hull fraction of $80 \%$ and above, discharge gate opening of $4 \mathrm{~mm}$ and low speed of $30 \mathrm{rev} / \mathrm{min}$. and below. It was observed that operating the machine with a speed of 50rpm led to slippage and eventual machine seizure. The machine may likely not be operated at high speed when loaded with materials. All the operations carried out on the machine were at 30rpm.

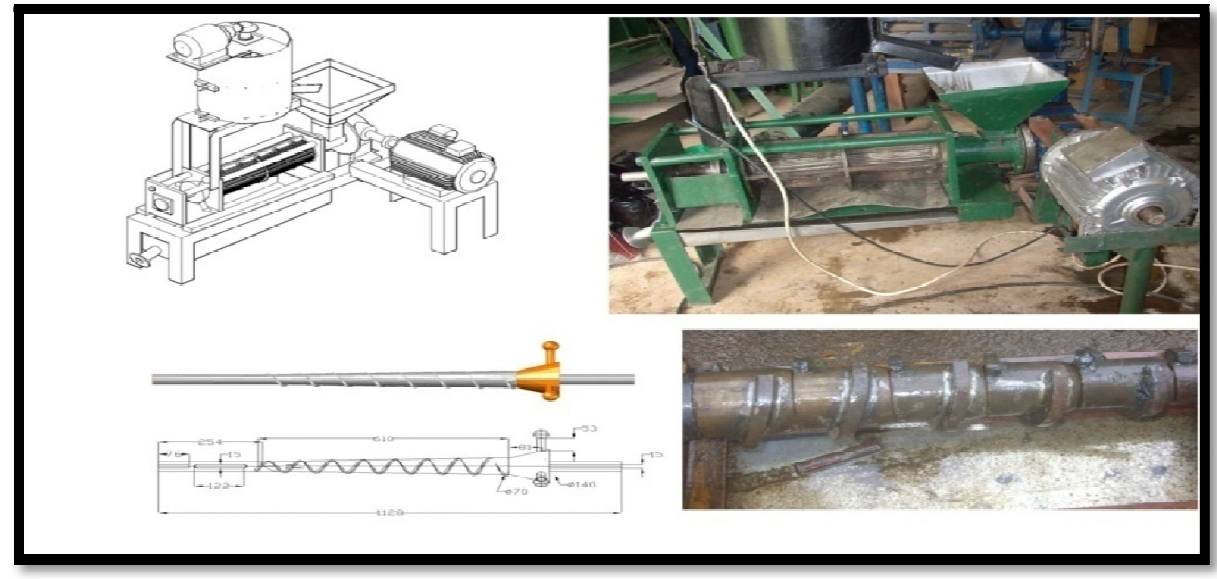

Figure 9: Designed and Fabricated Oil Expeller and Shaft

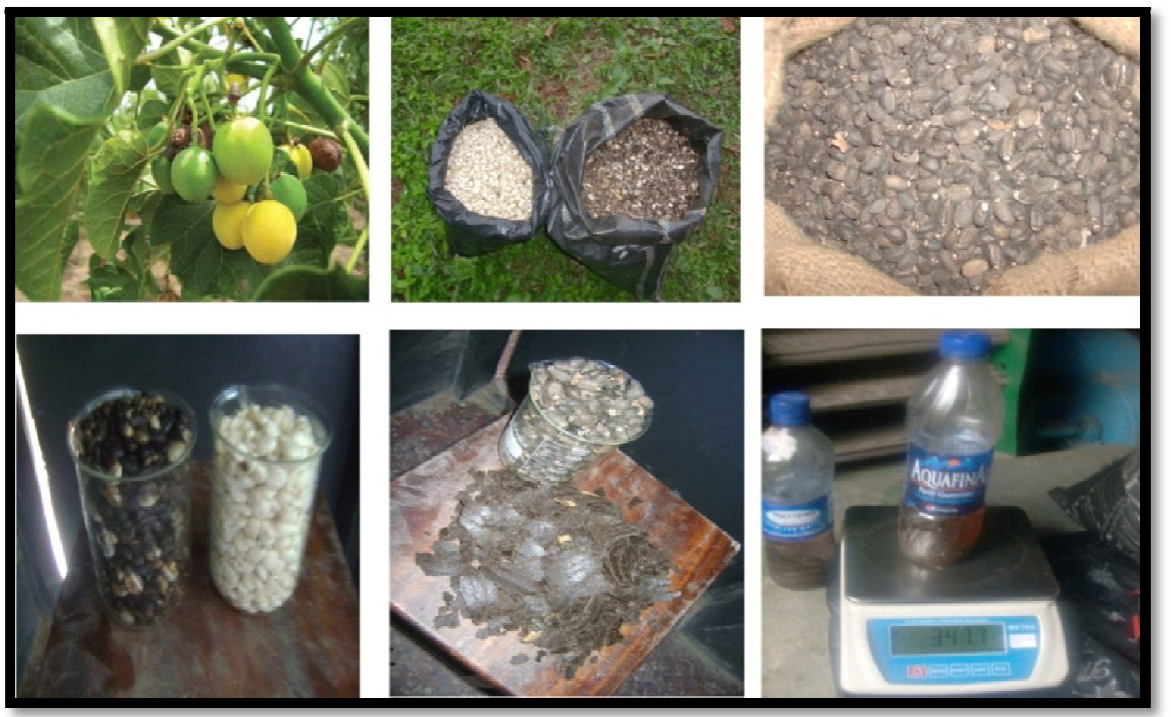

Figure 10: Materials, Main Product \& Bye Product of Combustion

Process (Jatropha Seeds: Both Decorticated and Un-Decorticated, Castor Seeds, Cake and Extracted Oil Measurement) 


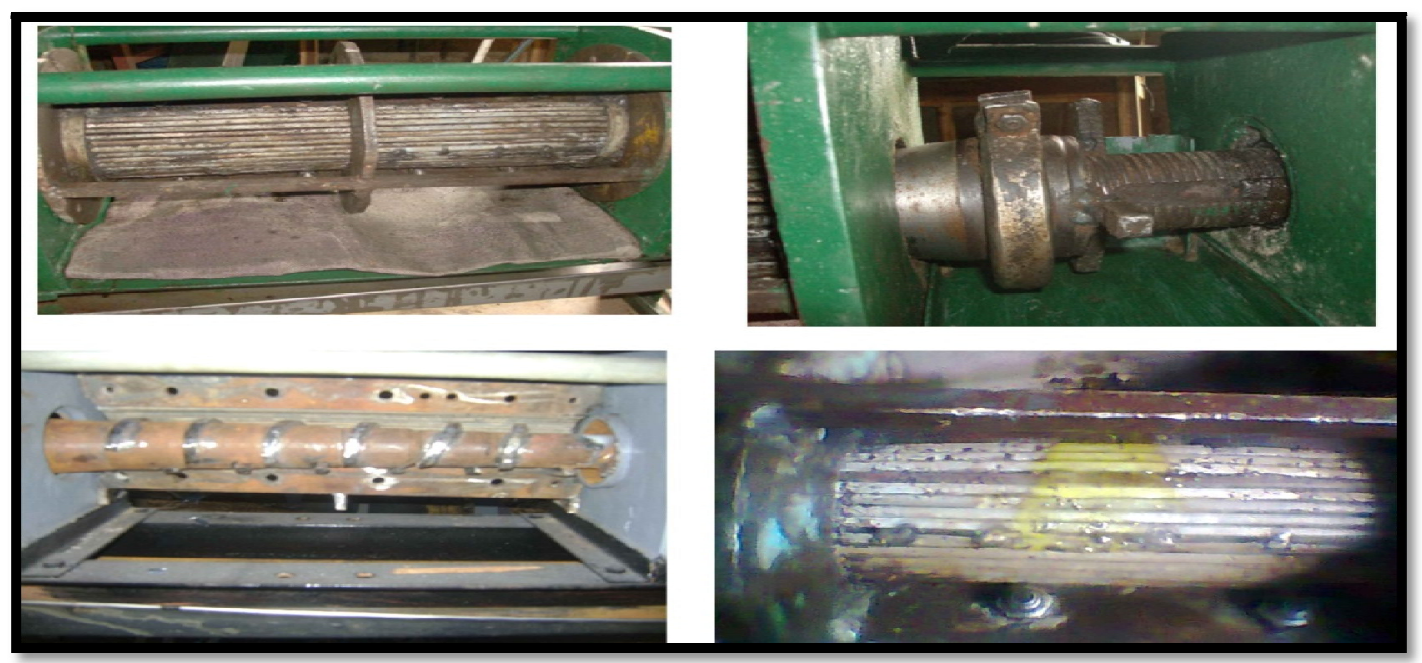

Figure 11: Some of the Major Component Parts of the Expeller

(Compression Chamber, Choke Adjuster, Sectioned View of Basket Cage and

Oil Point Section of Extraction Process)

\subsection{Physicochemical Characteristics of Jatropha Oil}

The physico-chemical properties like free fatty acid content, iodine value, unsaponifiable matter, triglyceride content, phosphorus content, etc. are very important for the evaluation of a given oil as biodiesel feed stock and for the definition of pretreatment procedures as well as the economy of the whole process. Some of the physico-chemical characteristics of Jatropha oil extracted are represented in Table 5 below.

Samples from three of the parameters varied were taken to a science laboratory for analysis. Sample A is the oil sample from double pass, sample D is the oil sample from hull fraction of $80 \%$ with $20 \mathrm{~min}$. heating time and sample E is the oil sample from cold pressing with hull fraction of $100 \%$ (when there was no preheating before pressing). See Appendix 2 for details.

Acid value, being a measure of free fatty acid and as well shelf life determinant is less $(4.3<4.6 \mathrm{mgKOH} / \mathrm{g})$ than the recommended value in the literature(International Journal of Basic \& Applied Sciences IJBAS-IJENS, 2012. Vol: 11 No: 06).Free fatty acid content depends on the quality and handling of seeds. Above the recommended value, the oil is not suitable for biodiesel production.

Iodine value in the table indicates application in the manufacture of alkyl resin, shoe polish, varnish, etc. Iodine value is a measure of degree of saturation of fatty acid in oil - high iodine value means more of unsaturation of fatty acid in the oil andlower iodine value means longer shelf life. Since the iodine value is less than recommended value $(92-95 \mathrm{gr}<$ 101.7-120 gr iodine/ 100gr, see appendix 6 of the main text for details), it means if the oil is used for biodiesel production, it will have longer shelf life.

Flash Point is the point at which flame from the oil can first ignite when mixed with air. The ignition temperature of the oil is less than the existing standard in the literature $\left(118<220^{\circ} \mathrm{C}\right.$, International Journal of Basic \& Applied Sciences IJBAS-IJENS, 2012. Vol: 11 No: 06) and the direct implication is that the oil is recommendable for biodiesel production.

Viscosity is a measure of resistance to flow of oil. Viscosity speaks of the volatility and ignition property when considered for biodiesel. The viscosity in the table (134-148 > 40.4 Centistoke) is far greater than the recommended value. This may be due to the fact that one of the processing conditions during extraction process is not favourable and the direct implication is that the oil will have low volatility property.

Majority of the parameters tested compare favourably with international standard (ASTM, IEA) on Physicochemical characteristics of Jatropha oil, except for viscosity. See appendix 6 for details on International standard on Physico-chemical Characteristics of Jatropha Oil. 


\begin{tabular}{|c|c|c|}
\hline Initial Oil Content (Solvent Extraction) & m\% oil/ Seed & 31.01\% (See App. 1) \\
\hline \multicolumn{3}{|c|}{ Oil recovery for single pass with varied hull fraction } \\
\hline Crude oil yield (100\% hull fraction) & $\mathrm{m} \%$ oil/ seed & $12.00 \%$ \\
\hline Crude oil efficiency (including fines) & $\mathrm{m} \%$ oil/ oil & $40.00 \%$ \\
\hline Crude oil yield (80\% hull fraction) & $\mathrm{m} \%$ oil/s & $13.43 \%$ \\
\hline Crude oil efficiency (including fines) & $\mathrm{m} \%$ oil/ oil & $54.80 \%$ \\
\hline Crude oil yield ( $60 \%$ hull) & $\mathrm{m} \%$ oil/ se & $7.85 \%$ \\
\hline Crude oil efficiency (including fines) & $\mathrm{m} \%$ oil/ & $26.17 \%$ \\
\hline Crude oil yield ( $40 \%$ hull) & $\mathrm{m} \%$ oil/se & $7.55 \%$ \\
\hline Crude oil efficiency (including fines) & $\mathrm{m} \%$ oil/ oil & $25.00 \%$ \\
\hline \multicolumn{3}{|c|}{ Oil recovery after pressing for double pass with $4 \mathrm{~mm}$ Restriction } \\
\hline Crude oil yield (100\% hull fraction) & $\mathrm{m} \% \mathrm{oil} / \mathrm{seed}$ & $12.00 \%$ \\
\hline Crude oil efficiency (including fines) & $\%$ oil/ oil & $40.00 \%$ \\
\hline Crude oil yield ( $80 \%$ hull fraction) & $\mathrm{m} \%$ oil/ seed & $13.43 \%$ \\
\hline Crude oil efficiency (including fines) & $\%$ oil/ oil & $44.80 \%$ \\
\hline Crude oil yield ( $60 \%$ hull) & $\mathrm{m} \% \mathrm{oil} / \mathrm{seed}$ & $7.85 \%$ \\
\hline Crude oil efficiency (including fines) & $\%$ oil/ oil & $26.17 \%$ \\
\hline Crude oil yield ( $40 \%$ hull) & $\mathrm{m} \%$ oil/ seed & $7.55 \%$ \\
\hline Crude oil efficiency (including fines) & $\%$ oil/ oil & $25.00 \%$ \\
\hline \multicolumn{3}{|c|}{ Oil recovery (single pass) with varied level of restriction } \\
\hline Crude oil yield (4mm restriction level) & $\mathrm{m} \% \mathrm{oil} / \mathrm{seed}$ & $12.53 \%$ \\
\hline Crude oil efficiency (including fines) & $\%$ oil/ oil & $42.00 \%$ \\
\hline Crude oil yield (6mm restriction level) & $\mathrm{m} \%$ oil/ seed & $9.31 \%$ \\
\hline Crude oil efficiency (including fines) & $\%$ oil/ oil & $31.03 \%$ \\
\hline Crude oil efficiency (including fines) & $\mathrm{m} \%$ oil/ seed & $24.31 \%$ \\
\hline Crude oil efficiency (including fines) & $\mathrm{m} \%$ oil/ seed & $24.31 \%$ \\
\hline \multicolumn{3}{|c|}{ Throughput capacity at varied restriction level } \\
\hline Capacity in $\mathrm{Kg} / \mathrm{hr}$. ( $6 \mathrm{~mm}$ restriction level) & - & $17.18 \mathrm{~kg} / \mathrm{hr}$. \\
\hline Capacity in $\mathrm{Kg} / \mathrm{hr}$. ( $6 \mathrm{~mm}$ restriction level) & - & $17.18 \mathrm{~kg} / \mathrm{hr}$. \\
\hline Capacity in $\mathrm{Kg} / \mathrm{hr}$. ( $8 \mathrm{~mm}$ restriction level) & - & $17.18 \mathrm{~kg} / \mathrm{hr}$ \\
\hline \multicolumn{3}{|c|}{ Oil recovery with heating time up to 30min (single pass) } \\
\hline Crude oil yield (cold pressing) & $\mathrm{m} \%$ oil/ seed & $12.53 \%$ \\
\hline Crude oil efficiency (including fines) & $\%$ oil/ oil & $42.00 \%$ \\
\hline Crude oil yield (10min. heating) & $\mathrm{m} \%$ oil/ seed & $9.31 \%$ \\
\hline Crude oil efficiency (including fines) & $\%$ oil/ oil & $31.03 \%$ \\
\hline Crude oil yield (20min. heating) & $\mathrm{m} \%$ oil/ seed & $7.30 \%$ \\
\hline Crude oil yield (20min. heating) & $\mathrm{m} \%$ oil/ seed & $7.30 \%$ \\
\hline Crude oil yield (30min heating) & $\mathrm{m} \%$ oil/ seed & $24.31 \%$ \\
\hline Crude oil yield (30min heating) & $\mathrm{m} \%$ oil/ seed & $24.31 \%$ \\
\hline Crude oil efficiency (including fines) & $\%$ oil/ oil & $24.31 \%$ \\
\hline
\end{tabular}

Table 10: Summary of Experimental Results for Jatropha Oil Extraction

\subsection{Bill of Materials for Construction of the Designed Oil Expeller}

Cost of engineering products like the newly constructed jatropha oil expeller can broadly be grouped under direct or indirect cost (Haslehurst, 1981). Direct cost is the cost of factors which are directly attributed to the manufacture of a specific product (i.e. materials and labour costs). Indirect cost on the other hand is that indirectly attributed to the manufacture of a specific product, such as overhead cost (usually expressed in percentage of direct labour cost).

The costing of the newly designed and constructed press was based on the detailed factorial estimate method (Sinnot, 1993). This is because construction of the machine is complete and detailed breakdown and estimation of the component parts is possible. The cost analysis of the machine is as in appendix 8 of the main text.

\section{Conclusions and Recommendations}

\subsection{Conclusions}

- Restriction size and rotational speed of the screw are two influential parameters. If high yields are required, restriction size should be reduced as far as possible taking into consideration operational limits of the press (as sudden seizure of main machine parts can occur when discharge outlet is clogged or too small, and when speed is too high).

- Oil yields drastically decreased with hull fraction below $80 \%$, from $80-100 \%$ the yield is hardly influenced negatively. It was equally observed that oil recovery at double pass was higher than that of single pass.

- Lower rotational speed led to higher oil recovery - this is mainly attributed to longer residence time. It should be noted that speed can only be reduced to a limited extent. 
- Clearance level of $2 \mathrm{~mm}$ led to clogging at the outlet section and eventual machine stoppage.

\subsection{Recommendations}

- The barrel should be bolted to the in-between stanchions on the frame of the expeller. This will increase the firmness of the compression chamber while the machine is in operation or when there is in-balance of main shaft.

- Additional research should be carried out using other relevant processes (ultrasonification/solvent extraction, hydraulic-hole screw pressing, etc.) to provide better insight on process efficiencies and viability that have closest resemblance with industrial practice.

- Repetition of press tests and measurements on oil recovery would increase the reliability of the results. Method of residual oil content can be used in place of oil mass method used throughout the experiment.

- Reverse switch should be introduced into electrical mechanism of the expeller and outlet should be provided for the discharge of the reverse operation at the peripheral of the machine. This will take care of challenge from power outage and sudden seizure of machine parts.

- Screw Geometry for jatropha oil extraction proposed in the literature (Taolu, 2007) can be considered when designing and fabricating another set of worms for the expeller main shaft. This will assist in optimisation of process efficiency - See appendix 5 for details.

\section{References}

i. Adebayo S.E. (2010). Design and Development of Jatropha Oil Expeller. Unpublished M.Sc.Thesis, Department of Agricultural and Environmental Engineering, University of Ibadan, Nigeria.

ii. Anjan B., Prusty K., Rachna C. and Azeez P.A. (2009). Biodiesel: Freedom from Dependence on Fossil Fuels. Environmental Impact Assessment Division, Salim Ali centre for ornithology and Natural History (SACON), Aanikatty(Po), Coimatore-641108 India. p. 002- 004.

iii. Beerens P. (2007). Screw Pressing of Jatropha Seeds for Fuelling Purposes in less Developed Countries. Eindhoven University of Technology, Department of Sustainable Energy Technology.

iv. Baldor Electric Company(2007). 5711 R.S. Boreham, Jr. St. P.O. Box 2400, Fort Smith, AR 72901. Chakrabarti

v. www.baldor.com Accessed, July 10, 2012.

vi. P.P. and Prasa R.B.N. (2010).Jatropha, Challenges for a New Energy Crop. Vol. 1 Farming and Economics.

vii. Haas, W. and Mittelbach, M. (2000), Detoxification experiments with the seed oil fromJatrophacurcas L: Industrial Crops and Products, v. 12, p. 111-118.

viii. Harmanto, A. Hendriadi, E. Rahmarestia, Mardison, and J. Wiyono, 2007.Test of a Screw-Press Machine forExtracting JatrophaCurcasSeed into Crude Oilas an Alternative Energy Source. Indonesian Center for Agricultural Engineering Research and Development Performance, Situgadung, Legok, Tangerang.IJETS|www.techsciencepub.com/ijets

ix. Haslehurst, M. (1981). Manufacturing Technology (3 ${ }^{\text {rd }}$ edition). Academic and Medical Publishing Division of Hodder and Stronghton, Bedford Square, London.

x. Physicochemical Properties and Fatty Acids Profile of Seed Oil of Telfairia occidentalis Hook, F (2012).International Journal of Basic \& Applied Sciences IJBAS-IJENS, Vol: 11 No: 06.

xi. Nicolas Carels, Mulpuri Sujatha and Bir Bahadur (2012). Jatropha Challenges for a New Energy Crop: Volume 1: Farming and Economics(619 pages).

xii. Rachimoellah H.M., Dyah Ayu Resti, Ali Zibbeni, Wayan Susila, I. (2008). Property Modification of Jatropha Oil Biodiesel. www.worldwidescience.org.

xiii. Sambo A.(2008). Nigeria uses Jatropha as a Source of Biofuels: The Energy Commission of Nigeria (ECN).

xiv. http:/ / www.thebioenergysite.com/ news/ 649/ nigeria-uses-jatropha-as-a-source-of-biofuel.AccessedonNov. 10th, 2011.

xv. Shahidi, F. (2005), Bailey's Industrial Oil \& Fat Products volume 5: "Edible oil \& fat products: Processing Technologies": New Jersey, John Wiley \& Sons, Inc... p. 15-75.

xvi. Sinnot, R.K. (1993). Chemical Engineering Volume 6. An Introduction to Chemical Engineering Design (1stedition). Pergamon International Library, Oxford New York.

xvii. Taulo John (2005). Design and Development of Screw Press. Research and Development, Malawi Industrial Research and Technology Development Centre.www.mirtdc@malawi.com. Accessed on Nov.3rd, 2011. 